\title{
When in Danger, Turn Right: Does Covid-19 Threat Promote Social Conservatism and Right-Wing Presidential Candidates?
}

\author{
Maciej Karwowski, Marta Kowal, Agata Groyecka, Michał Białek, Izabela Lebuda, \\ Agnieszka Sorokowska, and Piotr Sorokowski \\ University of Wrocław
}

Published as: Karwowski, M., Kowal, M., Groyecka, A., Białek, M., Lebuda, I., Sorokowska, A. \& Sorokowski, P. (2020). When in Danger, Turn Right: Does Covid-19 Threat Promote Social Conservatism and Right-Wing Presidential Candidates? Human Ethology, 35, 37-48, https://doi.org/10.22330/he/35/037-048

*Maciej Karwowski, Email: maciej.karwowski@uwr.edu.pl.0000-0001-6974-1673

Author Contributions: MKar, MK, AG, MB, IL, AS, and PS designed research; MKar, MK, AG, MB, IL, AS, and PS performed research; MKar analyzed data; and MKar, MK, AG, MB, IL, AS, and PS wrote the paper. Data availability statement: The data are available for review and third-party re-analyses. Polish dataset is available at:

https://figshare.com/s/67dc4d487942bb763a52. The US dataset is available at https://figshare.com/s/44a2f9ca24944e0bc156 


\begin{abstract}
Drawing upon the Parasite Model of Democratization across two preregistered experiments conducted in the USA and Poland (total $N=1,237$ ), we examined the psychological and political consequences of the recent COVID-19 pandemic. By manipulating saliency of COVID-19, we found that activating thinking about coronavirus may elevate Americans' and Poles' anxiety and indirectly promote their social conservatism all the way to support for more conservative presidential candidates. The pattern obtained was consistent in both countries, and it suggests that the pandemic may result in a shift in political views.
\end{abstract}

Keywords: pathogens, Behavioural Immune System, parasite stress, political preferences, social conservatism. 


\section{When in Danger, Turn Right: Does Covid-19 Threat Promote Social Conservatism and Right-Wing Presidential Candidates?}

Since December 2019, the world is facing an enormous challenge - a pandemic of COVID-19 (Ebrahim et al., 2020; Lipsitch et al., 2020). While COVID-19 pandemic's economic consequences are tackled in the literature (Baldwin \& di Mauro, 2020; McKibbin \& Fernando, 2020), still little is known about its social and political corollaries. As the spread of coronavirus coincides with presidential elections both in the United States and in Poland, we examine whether coronavirus influences political preferences. We hypothesized the pandemic would shift people into the more conservative end of the political spectrum, and we tested potential mechanisms of anxiety, need for structure, and conservatism.

When threatened by pathogens, such as SARS-CoV-2, people's default line of defence happens via somatic immune responses. These can be supplemented by various tendencies that constrain contacts with disease-causing parasites, a so-called behavioural immune system (Schaller \& Murray, 2008; Schaller \& Park, 2011). These tendencies range from cognitive, through motivational and affective to behavioural (Stevenson et al., 2012) and are collectively expediting detection and avoidance of potential disease carriers (Murray \& Schaller, 2013).

Reducing interpersonal contact forms a behavioural buffer against diseases, especially if contact is with outgroup members or novel objects. This is how the behavioural immune system works: once the risk of pathogens transmission is salient, 
people tend to be less extraverted and more risk averse (Schaller \& Murray, 2008), more ethnocentric (Navarrete \& Fessler, 2006), and more prejudiced toward unfamiliar outgroups (Faulkner et al., 2004). When prevalence of pathogens is large, such norms become culturally formalized, and start playing a role in shaping political ideologies. Specifically, pathogen prevalence seems to be related to collectivism (Fincher et al., 2008). In collectivistic countries, adherence to norms and traditions is especially pronounced (Schaller \& Murray, 2008; Thornhill et al., 2009). The tendency to distance oneself from strangers triggered by fear of contamination serves concurrently as a natural buffer against their ideas and diverse traditions or viewpoints.

One integrative framework that highlights the role of environmental threats in the formation of democratization has been proposed in a Parasite Model of Democratization (Thornhill et al., 2009). It posits that collectivism, autocracy, women's subordination relative to men's status, and women's sexual restrictiveness, all flourished in countries with prevalence of infectious diseases. The opposite ends of these values (individualism; democracy; women's rights, freedom and increased participation in casual sex) developed in countries with little to no prevalence of infectious diseases (Thornhill et al., 2009). Additional evidence comes from observations that liberalization of social values in Europe mirrored decreased prevalence of infectious diseases due to technological progress and that liberal ideologies are more frequent in 
regions of higher latitude, where parasite stress tends to be lower (Thornhill et al., 2009).

Several studies explicitly tested the hypothesis that social conservatism may be related to parasite stress. For example, in a study covering 30 nations, national parasite stress was related to traditionalism (Tybur et al., 2016). This hypothesis was also confirmed by a meta-analysis (Terrizzi et al., 2013), revealing that activation of the behavioural immune system was positively related to right-wing authoritarianism and political conservatism.

The outbreak of the COVID-19 pandemic is expected to activate the behavioural immune system in affected populations. Considering the solid theoretical framework, along with numerous studies (Jost et al., 2003; Terrizzi et al., 2013; Tybur et al., 2016), we hypothesize that exposure to cues of coronavirus (SARS-CoV-2) will elevate social conservatism. Following Terrizzi et al. (2013), we expect social conservatism only to increase as a function of parasite stress, because economic conservatism is not directly related to pathogen defence strategies (Johnson \& Tamney, 2001). This, in turn, can indirectly affect political choices of individuals and promote socially conservative candidates in elections.

We also investigate potential cognitive and affective mechanisms of this change. As the behavioural immune system emerges in order to protect humans from pathogens, a potential psychological mechanism driving this effect leads through the emotion of anxiety. Indeed, anxiety and uncertainty aversion are good candidates for triggering psychological motives that eventually lead to political conservatism (Jost et 
al., 2003; Nail et al., 2009). For instance, during periods of high social, political or economic threat, the appeal of right-wing conservatism is enhanced (Doty et al., 1991; McCann, 1997; Willer, 2004). Also, during threatening election years in the United States, highly conservative winners tended to obtain a wider victory margin, compared with non-threatening election years (McCann, 1997).

For cognitive mechanisms of how threat of pathogens could increase social conservatism, we consider the epistemic need for structure: a desire for predictability (Neuberg \& Newsom, 1993), as threat leads people to more conservative attitudes through motivation to avoid uncertain situations (Thórisdóttir \& Jost, 2011). The need for structure is correlated with conservatism (Jost \& Krochik, 2014; Van Hiel, Pandelaere, \& Duriez, 2004). An unpredictable pandemic that threatens all humans is very likely to strengthen the need to see structure in the world, as when threat is boosted people tend to seek a sense of comprehension of ongoing events (Bastian et al., 2019; Thórisdóttir \& Jost, 2011).

\section{The Present Study}

As the spread of pathogens (SARS-CoV-2) coincides with presidential elections both in the United States and in Poland, we sought to examine whether it influences political preferences through elevated anxiety, need for structure, and social conservatism. Across two preregistered experiments conducted in the USA and in Poland (total $N=$ 1,237) we manipulated saliency of COVID-19 and measured the consequences of this 
saliency on Americans' and Poles' anxiety, their need for structure, all the way to their social conservatism and support for presidential candidates.

\section{Method}

This research was preregistered. The registration protocols are available here https://osf.io/f9pgq.

\section{Participants}

The Polish part of the study involved 604 Polish adults (341 women, 57\%; age range: 18$90, M=39.47, S D=13.59$ ), while the US part involved 633 American adults (333 women, $53 \%$; age range $18-65, M=40.86, S D=13.00)$.

\section{Materials}

Anxiety. Participants' affect was measured using the international Positive and Negative Affect Scale short form (I-PANAS-SF; Thompson, 2007). The scale consists of 10 items: 5 measuring positive and 5 measuring negative affect. The reliability of positive and negative affect was acceptable in both countries: positive affect USA $\alpha=.76$ and Poland $\alpha=.67$; negative affect USA $\alpha=.82$ and Poland $\alpha=.87$. We investigated items related to anxiety. The "anxiety" variable was created by averaging two items ("nervous" and "afraid") in the USA ( $\alpha=.82)$ and three items in Poland ("nervous", afraid" and "alert", as the last adjective in the Polish language is semantically close to "concerned", $\alpha=.86$ ). For robustness check, we repeated all analyses for the Polish sample using only the same two adjectives as in the USA; the results were identical, apart from marginally weaker effects, likely caused by restriction range. See the Supplementary Online Materials (SOM) for complimentary analyses with both PANAS scales. 
Personal Need for Structure. Epistemic need for closure was measured by Neuberg and Newsom's (1993) Personal Need for Structure scale (PNS). PNS consists of 12 items (e.g. "I enjoy having a clear and structured mode of life"). Its reliability was satisfactory in both countries: USA $\alpha=.78$ and Poland $\alpha=.80$.

Conservatism. To measure participants' conservatism, we used a Social and Economic Conservatism Scale (SECS) (Everett, 2013). It consists of 12 items; participants declare their positivity or negativity toward each of the items using a 0-100 scale, with a predefined interval of 10 . Seven items are devoted to social conservatism (e.g. "traditional marriage") and 5 related to economic conservatism (e.g. "limited government"). Given the specificity of the Polish context, we omitted one item from the economic conservatism scale - "gun ownership," as it is irrelevant in a Polish reality due to restricted access to weapons by Polish law. Reliability of the social conservatism scale was appropriate in both samples: US $\alpha=.83$ and Poland $\alpha=.81$, while the economic conservatism scale reliability was poor, US $\alpha=.54$ and Poland $\alpha=.56$. The overall scale yielded good reliability in both countries, US $\alpha=.84$ and Poland $\alpha=.80$.

Political Preferences. Participants answered a set of questions regarding their political preferences. In both countries, participants were presented with leading presidential candidates. In the USA, they were Donald Trump as well as potential candidates of the Democratic party at the moment of data collection: Joe Biden, Bernie Sanders, Elizabeth Warren, Michael Bloomberg, and Tulsi Gabbard. In Poland, the candidates were: the current president - Andrzej Duda and registered candidates with the strongest support in election polls: Małgorzata Kidawa-Błońska, a candidate nominated by the leading 
opposition party: Civic Platform; Robert Biedroń, a candidate nominated by a leftist Democratic Left Alliance party; Władysław Kosiniak-Kamysz, nominated by Polish People's Party; Szymon Hołownia, an independent candidate, former media celebrity and writer; and Krzysztof Bosak, nominated by a right-wing Confederation party.

Questions answered in both countries concerned a candidate considered for voting (identified from a list of candidates; a multiple-choice question), as well as the first-choice candidate (a single-choice question). Both these variables were dummy coded for all candidates, with $0=$ not mentioned and $1=$ mentioned. Additionally, all participants evaluated the leading candidates' fit for the president's office using a 5point Likert scale (1 = a terrible candidate for presidency, $5=$ an excellent candidate for presidency). Country-specific questions were related to either a considered candidate's choice in the second round (specific for Poland, where two election rounds are organized if none of the candidates obtains more than $50 \%$ of votes) or perceived best candidate for democratic nominations with J. Biden and B. Sanders being included. Specific questions also addressed previous choices of the participants, namely, their voting decisions in 2015 in the US and in 2016 in Poland.

\section{Procedure}

The procedure consisted of two steps, presented to the participants as two studies. First, participants were randomly assigned to one of two groups and presented with three short press reports. In the control group, there were two neutral press reports and one press report about climate change, whereas in the experimental group, there were two neutral press reports (exactly the same as in the control group) and one press 
report about coronavirus outbreak. The press reports were equivalent and of similar length (i.e. English versions: 120-129 words; Polish versions: 100-106 words). Three single-choice questions regarding the content of each of the press reports served as attention check. We used only the data from participants who answered all of these questions correctly ( $7 \%$ of original sample was excluded). In the second part of the study, participants filled the I-PANAS-SF, PNS, SECS, and answered questions related to their political preferences and considered choices.

\section{Results}

Descriptive statistics and correlations between variables are available in the SOM (Table S1). Making coronavirus threat salient elevated the level of anxiety, with a stronger effect among Poles, $t(602)=5.86, p<.001, d=0.48,95 \% \mathrm{Cl}: 0.35,0.69$, than Americans, $t(631)=2.04, p=.04, d=0.16,95 \% \mathrm{Cl}: 0.01,0.35$. We note that data in Poland were collected on March 12th and in USA on March 13th. There were 44 Coronavirus positive cases (no deaths) in Poland on the date of the study, and 1,264 positive cases (and 36 deaths) in the US (WHO situation reports 52 and 53, 2020).

Participants indicated their considered candidates, as well as assessed each candidate's fit for the president's office. In both countries, we found a similar pattern of perceived fit and support for candidates. In the USA, the expected distinction occurred between D. Trump and all democratic candidates for the nomination, while in Poland, A. Duda and K. Bosak (a candidate of the right-wing Confederation party) formed a conservative pole, and the remaining candidates were clustered together (Figure 1). We created separate aggregate scores for both countries, with higher results denoting 
support for conservative candidates (Trump in the USA; Duda and Bosak in Poland), and lower scores indicating support for liberal and democratic candidates. The results of analyses conducted for candidates separately are presented in SOM (Tables S2-S5).

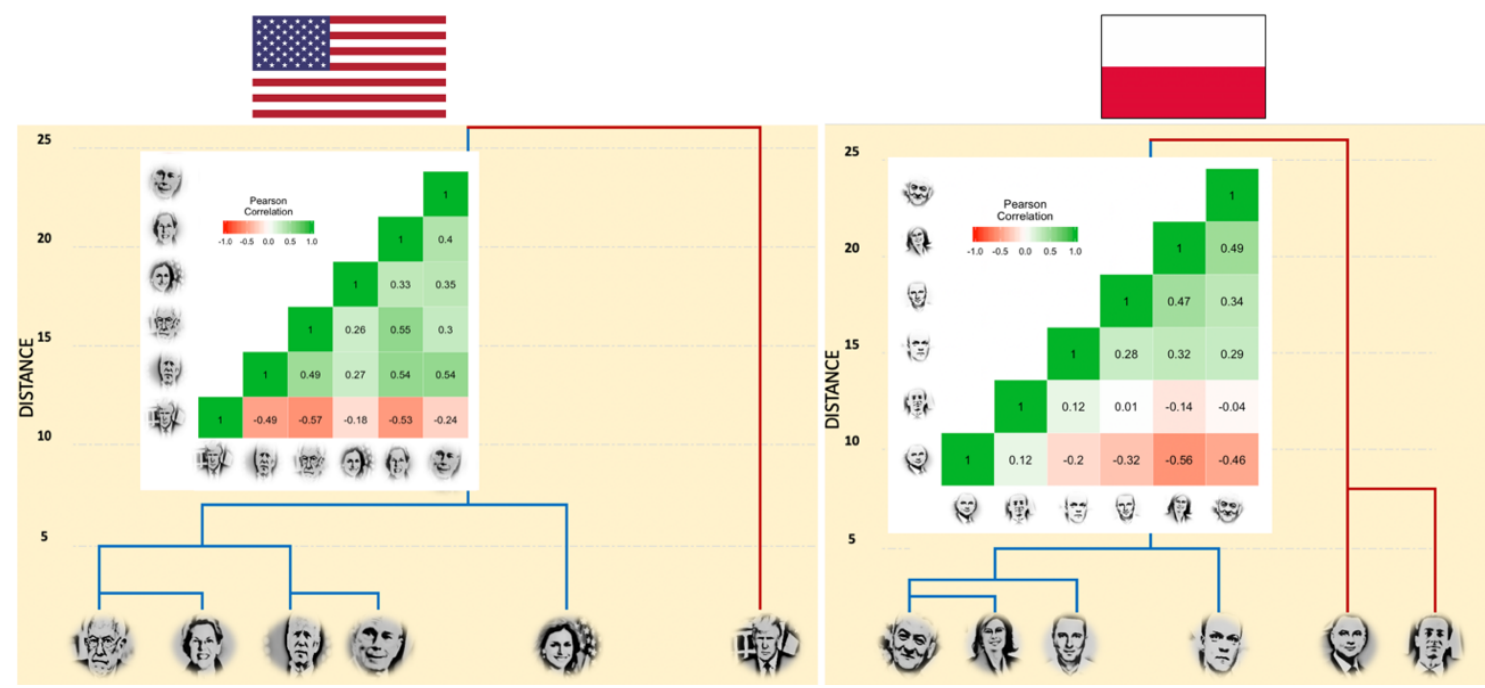

Figure 1. Distance between presidential candidates in the USA and Poland based on their perceived fit for the president's office. The red line indicates candidates who formed the conservative pole, while the blue line candidates were classified as liberals or democrats.

Our preregistered analysis posited sequential mediation (see e.g., Collins et al., 1998); we tested the extent to which anxiety caused by information about coronavirus 
translates into a higher personal need for structure, which then informs social conservatism and a tendency to support conservative presidential candidates. This reasoning found partial support in both countries (Figure 2). Among both Americans and Poles, increasing salience of coronavirus resulted in significantly higher anxiety, which then was linked to personal need for structure, which was correlated with social conservatism as well as support for conservative candidates and rejection of liberal ones. At the same time, direct effects of this chain of relationships were less consistent (see SOM, Tables S2-S5). Although making coronavirus salient indeed elevated anxiety, it did not directly predict neither personal need for structure, nor social conservatism in either of the countries. Similarly, although anxiety was significantly correlated with the personal need for structure, it was not linked to social conservatism in Poland while, unexpectedly, was negatively related to social conservatism in the USA.
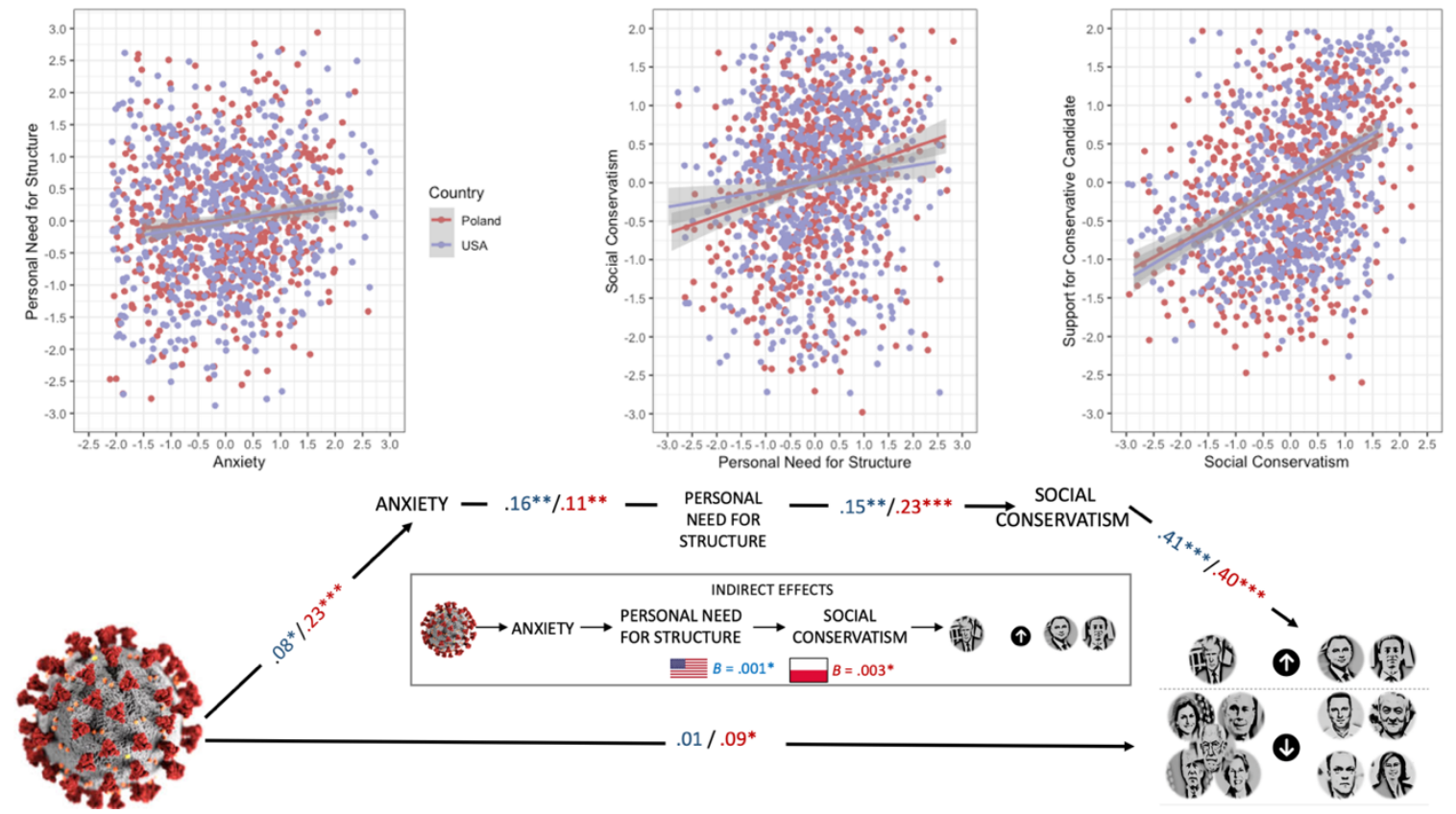

Figure 2. Sequential mediation illustrating that information about coronavirus elevates anxiety in both Americans (blue) and Poles (red), which then increases the personal 
need for structure and social conservatism. Finally, it results in higher support for conservative candidates in the USA and Poland. Values on the lines represent standardized regression coefficients.

There is an alternative explanation for why we found increased support for incumbent presidents over their alternatives. Indeed, they are both conservative, so their election constitutes a status quo. Therefore, participants threatened with coronavirus could increase their support for Trump and Duda for either of these reasons. The Polish case provides a useful comparison in terms of Bosak - a minority candidate (his support is lowest among all candidates tested, with about $4-5 \%$ of adult Poles declaring choosing this candidate in the first round of elections, http://ewybory.eu/wybory-prezydenckie-2020/sondaze-prezydenckie), and Bosak is more right-wing than Duda.

As Table 1 shows, the indirect effect we found was replicated when Bosak's overall fit for the president office was considered, but the effect was not significant when participants declared how they were actually going to vote. After increasing salience of the pandemic, we also observed decreased support for liberal candidates. Two potential democratic party candidates leading in the polls, namely Joe Biden and Bernie Sanders, who are moderate and liberal, have their mirror-like reflections on the Polish political stage: Małgorzata Kidawa-Błońska and Robert Biedroń, who are moderate and liberal, respectively. As illustrated in Table 1, when selecting from the 
two counter-candidates, people preferred moderate over leftist candidates. Specifically, people preferred Biden over Sanders, and Kidawa-Błońska over Biedroń.

Table 1. Unstandardized $b$ coefficients and their standard errors for the indirect link between coronavirus, anxiety, the personal need for structure, social conservatism, and support or declaration of voting for selected American and Polish candidates for the presidency.

\begin{tabular}{lllll}
\hline DV: & USA & & \\
\cline { 2 - 5 } & Sanders & Biden & & Trump \\
\hline \multirow{2}{*}{ Evaluation (Fit) } & $-0.0011^{*}$ & $-0.0004^{*}$ & & $0.0015^{*}$ \\
& $(0.0008)$ & $(0.0003)$ & & $(0.001)$ \\
Considering Voting & $-0.0017^{*}$ & $-0.0006^{*}$ & & $0.0023^{*}$ \\
& $(0.0012)$ & $(0.0004)$ & & $(0.001)$ \\
\hline & Poland & & & \\
\hline \multirow{4}{*}{ Evaluation (Fit) } & Biedroń & Kidawa-Błońska & Duda & Bosak \\
\cline { 2 - 5 } & $-0.0027^{*}$ & $-0.0019^{*}$ & $0.0043^{*}$ & $0.0009^{*}$ \\
\multirow{3}{*}{ Considering Voting } & $(0.0014)$ & $(0.001)$ & $(0.002)$ & $(0.0005)$ \\
& $-0.0053^{*}$ & $-0.0027^{*}$ & $0.0027^{*}$ & -0.0006 \\
& $(0.0027)$ & $(0.0014)$ & $(0.0096)$ & $(0.001)$ \\
\hline
\end{tabular}

${ }^{*} p<.05$

\section{Discussion}

This study tested a hypothesized shift in political views of individuals threatened by the coronavirus pandemic. We demonstrate that people who feel threatened react with anxiety, tend to seek greater structure in their environment, and thus, may shift toward social conservatism. All of this might increase the support for conservative presidential candidates, an effect also reported in parallel research with over 240,000 participants in the USA (Zmigrod et al., 2020), and during nationwide local election in France (AdamTroian et al, 2020). We emphasize the observed similarity of this effect in two countries: Poland and United States. Different in many aspects, these populations still exhibited the same pattern of results. 
Our results, although tentative, suggest that forthcoming elections could be biased toward conservative candidates - voters may seek stability exhibited by conservative candidates. Our findings might also have theoretical implications, as the current pandemic created an opportunity to test the Parasite Model of Democratization (Thornhill et al., 2009), entailing that pathogens-related threat can shape political orientations. We found support for it - pathogen threat boosted preference of values typical of social conservatism. We also provided evidence against an alternative explanation of threat boosting support for a status quo and evolutionarily formed avoidance of strangers (Faulkner et al., 2004), which can be extended to optional candidates, as support was also greater for less liberal alternative candidates, if participants were to choose among them.

Regarding applicability of our findings, we believe that all candidates may consider reframing their political communication. In the moral foundation theory (Graham et al., 2013; Haidt, 2012), loyalty and authority constitute the so-called binding values. These moral values are more prominent in conservatives, but, at the same time, are not ignored by liberally oriented individuals either. Therefore, communication appealing to these values may be an efficient way to mitigate the shift of values in societies: they are accepted by the core supporters of liberal candidates and are actively sought by individuals affected by the coronavirus threat.

Our study was conducted on March 12 in Poland, and March 13 in the USA, what entails important implications, as it was the beginning of massive, worldwide lockdowns (Le Quéré et al., 2020). At that time, transmission rates of COVID-19 were growing 
exponentially (Liu et al., 2020). Scholars observed high stress levels among people all around the world (Kowal et al., 2020), and increased psychological distancing to nations most affected by the pandemic (Sorokowski et al., 2020), what, altogether, may indicate an international crisis. For these reasons, our study provides an interesting opportunity to shed some more insight into a well-known phenomenon in political science - the socalled "rally 'round the flag" - an increased support for national leaders in times of a severe crisis (Mueller, 1970). Such effect has been already observed by Yam et al. (2020), who investigated daily approval ratings of government's heads in 11 countries worldwide during early months of the COVID-19 pandemic (i.e. from January 1, to April 30, 2020). In our study, indeed, the highest support was claimed for incumbent candidates (Trump in the USA, and Duda in Poland), but, notably, we have also observed an increase in support of a non-incumbent, more conservative candidate in Poland (i.e. Bosak), hence, the effects in Poland can only partly be explained by the "rally 'round the flag" effect (Mueller, 1970).

At the same time, there are a number of reasons why one should be cautious when considering our findings. First, although the present sequential mediation was indeed consistent with expectations, making the threat of COVID-19 salient did not directly predict neither personal need for structure, nor social conservatism. Second, although we did observe the expected positive links between anxiety and personal need for structure, anxiety alone did not predict social conservatism in Poland and was negatively related to social conservatism in the USA. The US pattern is contradictory to our expectation and might suggest reverse causality, i.e., that more conservative people 
are - for some reasons - less concerned with COVID-19. Third, and closely linked to the former, as all our mediators except anxiety were measured, yet not manipulated, strong causal claims are definitely premature and need further replications. Fourth, we collected limited information about our sample population, and thus, we do not know whether our participants may be considered representative regarding the US and Polish nations and our knowledge about the demographic structure of our samples is relatively narrow. However, large sample studies from the USA and France (Adam-Troian et al, 2020; Zmigrod et al., 2020) yielded similar results, what advocates in favour of the generalizability of our effects. Finally, we did not consider the role of emotion of disgust in shaping attitudes as a response to pathogens stress although it's role in diseaseavoidance is critical (e.g. Oaten, Stevenson, \& Case, 2009).

\section{Conclusions}

Across two preregistered experiments conducted in the US and Poland, we manipulated saliency of COVID-19 and measured the consequences of this saliency on Americans' and Poles' anxiety, their need for structure, all the way to their social conservatism and support for presidential candidates. Our results support this prediction by demonstrating that thinking about coronavirus can make Americans and Poles more anxious. Next, we observed that anxiety translates into a stronger personal need for closure, which in turn promotes social conservatism and support for more right-wing candidates. In general, our results highlight how important it is for people to perceive 
the world as a stable and predictable place. This preference is even stronger in times of chaos. 


\section{References}

Adam-Troian, J., Bonetto, E., Varet, F., Arciszewski, T., \& Guiller, T. (2020, June 7).

Pathogen threat increases electoral success for conservative parties: Results from a natural experiment with COVID-19 in France.

https://doi.org/10.31234/osf.io/aqkpm

Baldwin, R., \& di Mauro, B. W. (2020). Economics in the time of COVID-19. A VoxEU. org Book, Centre for Economic Policy Research, London. Accessed, 26.

Bastian, B., Vauclair, C. M., Loughnan, S., Bain, P., Ashokkumar, A., Becker, M., ... Swann, W. B. (2019). Explaining illness with evil: Pathogen prevalence fosters moral vitalism. Proceedings of the Royal Society B: Biological Sciences, 286(1914).

Doty, R. M., Peterson, B. E., \& Winter, D. G. (1991). Threat and authoritarianism in the United States, 1978-1987. Journal of Personality and Social Psychology, 61(4), 629.

Duckitt, J., Wagner, C., Du Plessis, I., \& Birum, I. (2002). The psychological bases of ideology and prejudice: Testing a dual process model. Journal of Personality and Social Psychology, 83(1), 75.

Collins, L. M., Graham, J. J., \& Flaherty, B. P. (1998). An alternative framework for defining mediation. Multivariate Behavioral Research, 33(2), 295-312.

Ebrahim, S. H., Ahmed, Q. A., Gozzer, E., Schlagenhauf, P., \& Memish, Z. A. (2020). Covid19 and community mitigation strategies in a pandemic. British Medical Journal Publishing Group.

Everett, J. A. C. (2013). The 12 item social and economic conservatism scale (SECS). PloS One, 8(12). 
Faulkner, J., Schaller, M., Park, J. H., \& Duncan, L. A. (2004). Evolved disease-avoidance mechanisms and contemporary xenophobic attitudes. Group Processes \& Intergroup Relations, 7(4), 333-353.

Fincher, C. L., Thornhill, R., Murray, D. R., \& Schaller, M. (2008). Pathogen prevalence predicts human cross-cultural variability in individualism/collectivism. Proceedings of the Royal Society B: Biological Sciences, 275(1640), 1279-1285.

Graham, J., Haidt, J., Koleva, S., Motyl, M., Iyer, R., Wojcik, S. P., \& Ditto, P. H. (2013). Moral foundations theory: The pragmatic validity of moral pluralism. In Advances in experimental social psychology (Vol. 47, pp. 55-130). Elsevier.

Haidt, J. (2012). The righteous mind: Why good people are divided by politics and religion. Vintage.

Johnson, S. D., \& Tamney, J. B. (2001). Social traditionalism and economic conservatism: Two conservative political ideologies in the United States. The Journal of Social Psychology, 141(2), 233-243.

Jost, J. T., Glaser, J., Kruglanski, A. W., \& Sulloway, F. J. (2003). Political conservatism as motivated social cognition. Psychological Bulletin, 129(3), 339.

Jost, J. T., \& Krochik, M. (2014). Ideological differences in epistemic motivation: Implications for attitude structure, depth of information processing, susceptibility to persuasion, and stereotyping. In Advances in motivation science (Vol. 1, pp. 181-231). Elsevier. 
Kowal, M., Coll-Martín, T., Ikizer, G., Rasmussen, J., Eichel, K., Studzinska, A., ... Ahmed, O. (2020, June 1). Who is the most stressed during COVID-19 isolation? Data from 27 countries. https://doi.org/10.31234/osf.io/qv5t7

Le Quéré, C., Jackson, R. B., Jones, M. W., Smith, A. J., Abernethy, S., Andrew, R. M., ... \& Friedlingstein, P. (2020). Temporary reduction in daily global CO 2 emissions during the COVID-19 forced confinement. Nature Climate Change, 1-7.

Lipsitch, M., Swerdlow, D. L., \& Finelli, L. (2020). Defining the epidemiology of Covid19-studies needed. New England Journal of Medicine.

Liu, Y., Gayle, A. A., Wilder-Smith, A., \& Rocklöv, J. (2020). The reproductive number of COVID-19 is higher compared to SARS coronavirus. Journal of Travel Medicine, 27(2).

McCann, S. J. H. (1997). Threatening times," strong" presidential popular vote winners, and the victory margin, 1824-1964. Journal of Personality and Social Psychology, 73(1), 1824-1964.

McKibbin, W. J., \& Fernando, R. (2020). The global macroeconomic impacts of COVID-19: Seven scenarios.

Miller, S. L., \& Maner, J. K. (2012). Overperceiving disease cues: The basic cognition of the behavioral immune system. Journal of Personality and Social Psychology, 102(6), 1198-1213.

Mueller, J. E. (1970). Presidential popularity from Truman to Johnson 1. American Political Science Review, 64(1), 18-34.

Murray, D. R., \& Schaller, M. (2013). The Behavioral Immune System: Implications for 
social cognition, social interaction, and social influence. In Advances in experimental social psychology (Vol. 53, pp. 75-129). Academic Press.

Nail, P. R., McGregor, I., Drinkwater, A. E., Steele, G. M., \& Thompson, A. W. (2009). Threat causes liberals to think like conservatives. Journal of Experimental Social Psychology, 45(4), 901-907.

Navarrete, C. D., \& Fessler, D. M. T. (2006). Disease avoidance and ethnocentrism: the effects of disease vulnerability and disgust sensitivity on intergroup attitudes. Evolution and Human Behavior, 27(4), 270-282.

Neuberg, S. L., \& Newsom, J. T. (1993). Personal need for structure: Individual differences in the desire for simpler structure. Journal of Personality and Social Psychology, 65(1), 113-131.

Schaller, M., \& Murray, D. R. (2008). Pathogens, personality, and culture: Disease prevalence predicts worldwide variability in sociosexuality, extraversion, and openness to experience. Journal of Personality and Social Psychology, 95(1), 212221.

Schaller, M., \& Park, J. H. (2011). The behavioral immune system (and why it matters). Current Directions in Psychological Science, 20(2), 99-103.

Oaten, M., Stevenson, R. J., \& Case, T. I. (2009). Disgust as a disease-avoidance mechanism. Psychological Bulletin, 135(2), 303.

Sorokowski, P., Groyecka, A., Kowal, M., Sorokowska, A., Bialek, M., Lebuda, I., ... Karwowski, M. (2020). Can information about pandemics increase negative attitudes toward foreign groups? A case of COVID-19 outbreak. Sustainability, 12. 
Stevenson, R. J., Hodgson, D., Oaten, M. J., Moussavi, M., Langberg, R., Case, T. I., \& Barouei, J. (2012). Disgust elevates core body temperature and up-regulates certain oral immune markers. Brain, Behavior, and Immunity, 26(7), 1160-1168.

Terrizzi, J. A., Shook, N. J., \& McDaniel, M. A. (2013). The behavioral immune system and social conservatism: A meta-analysis. Evolution and Human Behavior, 34(2), 99108.

Thompson, E. R. (2007). Development and validation of an internationally reliable shortform of the positive and negative affect schedule (PANAS). Journal of CrossCultural Psychology, 38(2), 227-242.

Thórisdóttir, H., \& Jost, J. T. (2011). Motivated closed-mindedness mediates the effect of threat on political conservatism. Political Psychology, 32(5), 785-811.

Thornhill, R., Fincher, C. L., \& Aran, D. (2009). Parasites, democratization, and the liberalization of values across contemporary countries. Biological Reviews, 84(1), 113-131.

Tybur, J. M., Inbar, Y., Aarøe, L., Barclay, P., Barlowe, F. K., De Barra, M., ... Žezelj, I. (2016). Parasite stress and pathogen avoidance relate to distinct dimensions of political ideology across 30 nations. Proceedings of the National Academy of Sciences of the United States of America, 113(44), 12408-12413.

Van Hiel, A., Pandelaere, M., \& Duriez, B. (2004). The impact of need for closure on conservative beliefs and racism: Differential mediation by authoritarian submission and authoritarian dominance. Personality and Social Psychology Bulletin, 30(7), 824-837. 
WHO. (2020) Coronavirus disease (COVID-19) Situation dashboard. Retrieved from: https://covid19.who.int

WHO. (2020). WHO calls for urgent, aggressive actions to combat COVID-19, as cases soar in South-East Asia Region. Retrieved from https://www.who.int/southeastasia/news/detail/17-03-2020-who-calls-forurgent-aggressive-actions-to-combat-covid-19-as -cases-soar-in-south-eastasia-region

Willer, R. (2004). The effects of government-issued terror warnings on presidential approval ratings. Current Research in Social Psychology, 10(1), 1-12.

Yam, K. C., Jackson, J. C., Barnes, C. M., Lau, T., QIN, X., \& Lee, H. Y. (2020, May 18). The Rise of COVID-19 is associated with support for world leaders. https://doi.org/10.31234/osf.io/jhprk

Zmigrod, L., Ebert, T., Götz, F. M., \& Rentfrow, J. (2020). The psychological and sociopolitical consequences of infectious diseases. PsyArXiv. 
Supplementary Online Material for

When in Danger, Turn Right: Does Covid-19 Threat Promote Social Conservatism and Right-Wing

Presidential Candidates?

Table S1. Descriptive Statistics and Correlations between Variables used in the Study in Poland and the USA

\begin{tabular}{|c|c|c|c|c|c|c|c|c|c|c|c|c|}
\hline & \multirow[b]{2}{*}{ Variables } & \multicolumn{2}{|c|}{ Poland $(n=604)$} & \multirow[b]{2}{*}{1} & \multirow[b]{2}{*}{2} & \multirow[b]{2}{*}{3} & \multirow[b]{2}{*}{4} & \multirow[b]{2}{*}{5} & \multirow[b]{2}{*}{6} & \multirow[b]{2}{*}{7} & \multirow[b]{2}{*}{8} & \multirow[b]{2}{*}{9} \\
\hline & & $\mathrm{M}$ & SD & & & & & & & & & \\
\hline 1 & Manipulation & .48 & .50 & 1 & .23 & .23 & .19 & .02 & -.03 & .03 & .05 & .03 \\
\hline 2 & Anxiety & 2.72 & 1.11 & & 1 & .96 & .95 & .03 & .10 & .04 & .01 & .03 \\
\hline 3 & Anxiety2 & 2.51 & 1.14 & .08 & -- & 1 & .94 & -.02 & .07 & .02 & -.01 & .01 \\
\hline 4 & PANAS-neg & 0.00 & 1.00 & .04 & -- & .89 & 1 & .00 & .07 & .00 & -.03 & -.01 \\
\hline 5 & PANAS-pos & 0.00 & 1.00 & .03 & -- & .02 & .00 & 1 & .14 & .16 & .18 & .15 \\
\hline 6 & PNS & 4.12 & 0.67 & -.02 & -- & .16 & .11 & .05 & 1 & .21 & .05 & .23 \\
\hline 7 & Conservatism (all) & 69.77 & 15.20 & .03 & -- & -.19 & -.17 & .22 & .10 & 1 & .67 & .97 \\
\hline 8 & Conservatism (econ) & 65.06 & 16.13 & .03 & -- & -.17 & -.15 & .18 & .03 & .82 & 1 & .52 \\
\hline 9 & Conservatism (social) & 71.61 & 16.75 & .03 & -- & -.17 & -.15 & .20 & .12 & .94 & .59 & 1 \\
\hline USA & $\mathrm{M}$ & & & .51 & -- & 2.63 & 0.00 & 0.00 & 4.10 & 62.49 & 57.20 & 66.26 \\
\hline$(n=633)$ & SD & & & .50 & -- & 1.10 & 1.00 & 1.00 & 0.70 & 17.52 & 17.19 & 21.09 \\
\hline
\end{tabular}

Note. Correlations for Poland are above the diagonal, correlations for the USA are below the diagonal.

Anxiety $=$ anxiety variable composed of three adjectives (Poland), Anxiety2 $=$ anxiety variable composed of

the same two adjectives in both countries. PANAS-neg and PANAS-pos = PANAS negative affect and

positive affect scales, obtained in exploratory factor analyses with varimax rotation and saved as factor

$\operatorname{scores}(M=0, S D=1)$

Table S2. A summary of mediation models predicting the readiness to vote for each of the candidates in the USA.

\begin{tabular}{|l|c|c|c|c|c|c|c|c|c|}
\hline Predictors & \multicolumn{3}{|c|}{ Mediators } & \multicolumn{9}{c|}{ DV: Voting for } \\
\hline & $\begin{array}{c}\text { Anxiety } \\
\text { (M1) }\end{array}$ & PNS (M2) & SC (M3) & BS & EW & JB & MB & TG & DT \\
\hline Coronavirus & $0.09^{*}$ & -0.02 & 1.03 & -0.14 & -0.20 & 0.05 & -0.29 & -0.21 & 0.12 \\
(Manipulation) & $(0.04)$ & $(0.03)$ & $(0.82)$ & $(0.09)$ & $(0.14)$ & $(0.09)$ & $(0.15)$ & $(0.21)$ & $(0.09)$ \\
\hline Anxiety (M1) & -- & $0.10^{* * *}$ & $-3.75^{* * *}$ & -0.02 & -0.09 & -0.09 & 0.18 & 0.02 & -0.14 \\
& & $(0.03)$ & $(0.76)$ & $(0.09)$ & $(0.13)$ & $(0.08)$ & $(0.14)$ & $(0.20)$ & $(0.09)$ \\
\hline PNS (M2) & -- & -- & $4.56^{* * *}$ & $0.35^{* *}$ & 0.17 & $0.33^{* *}$ & -0.20 & -0.20 & $-0.35^{* *}$ \\
& & & $(1.18)$ & $(0.14)$ & $(0.19)$ & $(0.13)$ & $(0.22)$ & $(0.29)$ & $(0.14)$ \\
\hline SC (M3) & -- & -- & -- & $-0.04^{* * *}$ & $-0.04^{* * *}$ & $-0.02^{* *}$ & 0.008 & $-0.02^{*}$ & $0.06^{* * *}$ \\
& & & & $(0.005)$ & $(0.007)$ & $(0.004)$ & $(0.008)$ & $(0.01)$ & $(0.001)$ \\
\hline
\end{tabular}


$\mathrm{DV}=$ voting for: $\mathrm{BS}=$ Bernie Sanders, $\mathrm{EW}=$ Elizabeth Warren, $\mathrm{JB}=$ Joe Biden, $\mathrm{MB}=$ Michael

Bloomberg, TG = Tulsi Gabbard, DT = Donald Trump, PNS = Personal Need for Structure, $\mathrm{SC}=$

Social Conservatism. $M 1=1^{\text {st }}$ mediator, $M 2=2^{\text {nd }}$ mediator, $M 3=3^{\text {rd }}$ mediator.

Table S3. A summary of mediation models predicting the perceived fit for the presidency of each of the candidates in the USA.

\begin{tabular}{|l|c|c|c|c|c|c|c|c|c|}
\hline Predictors & \multicolumn{3}{|c|}{ Mediators } & \multicolumn{6}{c|}{ DV: Positive fit for presidency: } \\
\hline & $\begin{array}{c}\text { Anxiety } \\
\text { (M1) }\end{array}$ & $\begin{array}{c}\text { PNS } \\
\text { (M2) }\end{array}$ & SC (M3) & BS & EW & JB & MB & TG & DT \\
\hline Coronavirus & $0.09^{*}$ & -0.02 & 1.03 & -0.06 & -0.01 & 0.01 & -0.04 & 0.004 & -0.001 \\
(Manipulation) & $(0.04)$ & $(0.03)$ & $(0.82)$ & $(0.05)$ & $(0.05)$ & $(0.05)$ & $(0.05)$ & $(0.04)$ & $(0.06)$ \\
\hline Anxiety (M1) & -- & $0.10^{* * *}$ & $-3.75^{* * *}$ & $0.14^{*}$ & $0.10^{*}$ & $0.12^{*}$ & $0.16^{* *}$ & 0.03 & -0.003 \\
& & $(0.03)$ & $(0.76)$ & $(0.05)$ & $(0.04)$ & $(0.05)$ & $(0.05)$ & $(0.04)$ & $(0.05)$ \\
\hline PNS (M2) & -- & -- & $4.56^{* * *}$ & 0.06 & 0.03 & $0.16^{*}$ & -0.13 & -0.01 & $-0.27^{* *}$ \\
& & & $(1.18)$ & $(0.08)$ & $(0.07)$ & $(0.08)$ & $(0.07)$ & $(0.06)$ & $(0.08)$ \\
\hline SC (M3) & -- & -- & -- & $-0.03^{* * *}$ & $-0.02^{* * *}$ & $-0.01^{* *}$ & 0.003 & -0.03 & $0.04^{* * *}$ \\
& & & & $(0.003)$ & $(0.002)$ & $(0.003)$ & $(0.002)$ & $(0.002)$ & $(0.003)$ \\
\hline
\end{tabular}

$\mathrm{DV}=$ Fit for presidency: $\mathrm{BS}=$ Bernie Sanders, $\mathrm{EW}=$ Elizabeth Warren, $\mathrm{JB}=$ Joe Biden, $\mathrm{MB}=$

Michael Bloomberg, TG = Tulsi Gabbard, DT = Donald Trump, PNS = Personal Need for Structure,

$\mathrm{SC}=$ Social Conservatism. $\mathrm{M} 1=1^{\text {st }}$ mediator, $\mathrm{M} 2=2^{\text {nd }}$ mediator, $\mathrm{M} 3=3^{\text {rd }}$ mediator.

Table S4. A summary of mediation models predicting the readiness to vote for each of the candidates in Poland

\begin{tabular}{|l|c|c|c|c|c|c|c|c|c|}
\hline Predictors & \multicolumn{3}{|c|}{ Mediators } & \multicolumn{7}{c|}{ DV: Voting for } \\
\hline & $\begin{array}{c}\text { Anxiety } \\
\text { (M1) }\end{array}$ & $\begin{array}{c}\text { PNS } \\
\text { (M2) }\end{array}$ & SC (M3) & RB & MKB & WKK & SH & AD & KB \\
\hline Coronavirus & $0.26^{* * *}$ & -0.04 & 0.66 & 0.13 & -0.14 & -0.18 & 0.03 & 0.04 & 0.13 \\
(Manipulation) & $(0.04)$ & $(0.03)$ & $(0.69)$ & $(0.12)$ & $(0.11)$ & $(0.11)$ & $(0.11)$ & $(0.09)$ & $(0.15)$ \\
\hline Anxiety (M1) & -- & $0.07^{* *}$ & -0.03 & 0.07 & -0.01 & -0.001 & 0.11 & -0.03 & 0.13 \\
& & $(0.03)$ & $(0.62)$ & $(0.11)$ & $(0.10)$ & $(0.11)$ & $(0.10)$ & $(0.08)$ & $(0.14)$ \\
\hline PNS (M2) & -- & -- & $5.80^{* * *}$ & -0.12 & -0.03 & 0.10 & 0.19 & -0.10 & 0.15 \\
& & & $(1.00)$ & $(0.17)$ & $(0.15)$ & $(0.17)$ & $(0.17)$ & $(0.13)$ & $(0.23)$ \\
\hline SC (M3) & -- & - & -- & $-0.05^{* * *}$ & $-0.03^{* * *}$ & $-0.02^{* *}$ & -0.001 & $0.04^{* * *}$ & -0.006 \\
& & & & $(0.007)$ & $(0.006)$ & $(0.007)$ & $(0.007)$ & $(0.006)$ & $(0.009)$ \\
\hline
\end{tabular}

$\mathrm{DV}=$ voting for: $\mathrm{RB}=\mathrm{R}$. Biedroń, $\mathrm{MKB}=\mathrm{M}$. Kidawa-Błońska, $\mathrm{WKK}=\mathrm{W}$. Kosiniak-Kamysz, $\mathrm{SH}=\mathrm{S}$.

Hołownia, $A D=A$. Duda, KB $=$ K. Bosak, PNS $=$ Personal Need for Structure,$S C=$ Social

Conservatism. $\mathrm{M} 1=1^{\text {st }}$ mediator, $\mathrm{M} 2=2^{\text {nd }}$ mediator, $\mathrm{M} 3=3^{\text {rd }}$ mediator. 
Table S5. A summary of mediation models predicting the perceived fit for the presidency of each of the candidates in Poland.

\begin{tabular}{|l|c|c|c|c|c|c|c|c|c|}
\hline Predictors & \multicolumn{3}{|c|}{ Mediators } & \multicolumn{5}{c|}{ DV: Positive fit for presidency: } \\
& $\begin{array}{c}\text { Anxiety } \\
\text { (M1) }\end{array}$ & $\begin{array}{c}\text { PNS } \\
\text { (M2) }\end{array}$ & SC (M3) & RB & MKB & WKK & SH & AD & KB \\
\hline Coronavirus & $0.26^{* * *}$ & -0.04 & 0.66 & $0.03(0.05)$ & -0.05 & -0.06 & -0.002 & 0.09 & $0.14^{* *}$ \\
(Manipulation) & $(0.04)$ & $(0.03)$ & $(0.69)$ & & $(0.05)$ & $(0.04)$ & $(0.04)$ & $(0.06)$ & $(0.04)$ \\
\hline Anxiety (M1) & -- & $0.07^{* *}$ & -0.03 & $0.07(0.04)$ & 0.06 & $0.09^{*}$ & $0.12^{* *}$ & 0.03 & 0.06 \\
& & $(0.03)$ & $(0.62)$ & & $(0.05)$ & $(0.04)$ & $(0.04)$ & $(0.05)$ & $(0.04)$ \\
\hline PNS (M2) & -- & -- & $5.80^{* * *}$ & -0.02 & 0.01 & 0.02 & 0.04 & -0.06 & -0.04 \\
& & & $(1.00)$ & $(0.07)$ & $(0.08)$ & $(0.06)$ & $(0.06)$ & $(0.08)$ & $(0.06)$ \\
\hline SC (M3) & -- & -- & -- & $-0.03^{* * *}$ & - & - & 0.001 & $0.04^{* * *}$ & $0.01^{* *}$ \\
& & & & $(0.003)$ & $0.02^{* * *}$ & $0.01^{* *}$ & $(0.003)$ & $(0.003)$ & $(0.002)$ \\
& & & & & $(0.003)$ & $(0.003)$ & & & \\
\hline
\end{tabular}

$\mathrm{DV}=$ fit for presidency: $\mathrm{AD}=\mathrm{A}$. Duda, $\mathrm{RB}=\mathrm{R}$. Biedroń, $\mathrm{MKB}=\mathrm{M}$. Kidawa-Błońska, $\mathrm{WKK}=\mathrm{W}$.

Kosiniak-Kamysz, $\mathrm{SH}=\mathrm{S}$. Hołownia, $\mathrm{KB}=\mathrm{K}$. Bosak

PNS = Personal Need for Structure, $\mathrm{SC}=$ Social Conservatism 